\title{
Living degrowth? Investigating degrowth practices through performative methods
}

\author{
Johannes Brossmann ${ }^{1,2} \cdot$ Mine Islar $^{3}$ (D)
}

Received: 27 February 2019 / Accepted: 6 November 2019 / Published online: 18 November 2019

(c) The Author(s) 2019

\begin{abstract}
Degrowth scholarship argues for multi-scalar transformations beyond the growth-oriented economic paradigm to achieve long-term socio-ecological sustainability. While the literature on degrowth has grown substantially, little has been said about how these transformations are understood in practice. By drawing upon practice theory and using performative methods, this paper explores the ways in which degrowth scholars and practitioners experience and understand degrowth. It provides a preliminary account of living degrowth by portraying a diverse range of interrelated practices grouped in five spheres: (1) rethinking society, (2) acting political, (3) creating alternatives, (4) fostering connections, and (5) unveiling the self. Drawing upon the spheres of practices, we conceptualize living degrowth as an endeavour that aims to transform current problems into imagined futures in multiple realms. The practices of living degrowth are concerned with theoretical, political, material, economical, social and personal dimensions of world and life. This points to the importance for sustainability science to investigate and foster transformations in all domains and at all levels, reaching from the outer to the inner and vice versa.
\end{abstract}

Keywords Degrowth $\cdot$ Performative methods $\cdot$ Sustainability science $\cdot$ Practices $\cdot$ Transformations $\cdot$ Inner worlds

\section{Introduction}

The recent UN-backed IPBES report on the current status on biodiversity loss emphasizes the urgent need for transformation especially in our economic system and social values associated with economic growth (Diaz et al. 2019). The

Handled by J. David Tàbara, Institute of Environmental Science and Technology, Barcelona, Spain.

Electronic supplementary material The online version of this article (https://doi.org/10.1007/s11625-019-00756-y) contains supplementary material, which is available to authorized users.

Mine Islar

mine.islar@lucsus.lu.se

Johannes Brossmann

johannes.brossmann@posteo.at

1 LUMES (Lund University's International Master Programme in Environmental Studies and Sustainability Science), Lund, Sweden

2 actinGreen (Non-Profit Association for Theatre Pedagogy and Sustainability), Vienna, Austria

3 LUCSUS (Lund University Centre for Sustainability Studies), Lund, Sweden report's conclusions are clear: "A key component of sustainable pathways is the evolution of global financial and economic systems to build a global sustainable economy, steering away from the current, limited paradigm of economic growth." (Diaz et al. 2019, p 10). For several decades, the environmental movement has addressed humanity's impact on the environment and identified economic growth as a key driver for unsustainability (Meadows 1972). However, the paradigms of sustainable development and ecological modernisation attempted to solve the tension between economy and environment, but actually perpetuated to 'sustain the unsustainable' (Blühdorn 2007). With an ambition to end the depoliticizing consensus on sustainable development (Kallis et al. 2015), degrowth has emerged in the last decade as a frame for a re-politicized, re-radicalized critique of capitalist growth society by proposing radical change (Demaria et al. 2013). Degrowth argues for multi-scalar transformations beyond capitalism to achieve long-term socio-ecological sustainability (Asara et al. 2015).

Evoked by the degrowth discourse, we want to specify our interpretation of transformation. While understandings of transformations are diverse, fragmented and contested, they generally describe profound irreversible change at agency and structural levels (Brown et al. 2013). Such changes 
take place across multiple dimensions and scales (O'Brien 2012), concerning individuals, society, institutions, technology, economy and ecology as well as "practices, lifestyles, power relations, norms and values" (Brown et al. 2013, p. 101). Deliberate transformations are related to questioning deep drivers that caused problems of unsustainability in the first place (O'Brien 2012). In this sense, degrowth questions root causes of unsustainability like economic growth and differs from sustainability approaches that only promote transition and reforms within the existing economic and social order (Asara et al. 2015). Furthermore, degrowth suggests a paradigmatic re-ordering of values through reaffirmation of social and ecological values (Kallis et al. 2015).

While the literature on degrowth has grown substantially, there are questions about how degrowth transformations can be achieved. To contribute to this debate, we will first and foremost study the subjects of degrowth transformations, as in the individual agents who (want to) take part in changing society towards more socio-ecological sustainability. In fact, looking at the subject of degrowth ${ }^{1}$ and taking a subjective perspective seems to be a relevant contribution to degrowth literature.

By looking at degrowth as more than an academic debate, but as a "frame constituted by a large array of concerns, goals, strategies and actions" (Demaria et al. 2013), our first aim is to ask how individuals interpret the degrowth vocabulary and in which practices they see it embodied. To fit this aim, we decided to build upon practice theory (Kemmis et al. 2014b) to capture the ways in which degrowth is understood, materialized and practiced. While we acknowledge that portraying agents of transformations could also be done through other theoretical frameworks, e.g., sustainability learning (cf. Tàbara and Pahl-Wostl 2007), we refrained from adopting such a social-ecological complex systems perspective, because it requires an in-depth analysis of single cases, which was not the goal of this study.

Practice theory, in turn, is useful to our research for two reasons: (1) it suits our aim to investigate degrowth from a subjective perspective, because it considers practitioners and their practices, thus acknowledging agency. (2) It considers the importance of structures in shaping humans' actions by describing the role of practice architectures. Hence, this theory integrates agency and structure without over- or underrating either of them. By including cultural-discursive, material-economic and social-political aspects it takes a holistic ontological view, seeing the social world not as purely discursively, nor as only materially or relationally constituted, but as a bundle of all those. To capture this, we

\footnotetext{
${ }^{1}$ Here and hereafter we will keep referring to the subject of degrowth in the sense of individual agents of degrowth, not in the synonymous meaning of the "topic" of degrowth.
}

put forward the notion of living degrowth. It is used as a general idea with a double meaning, where it can be understood as (1) lived experiences by those individuals that reshape their lives to reflect this inspiration, and (2) as a collective evolving endeavour with a "living and dynamic set of ideas" (Flipo and Schneider 2015). In this context, our paper answers the following questions: what does it mean to 'live degrowth'? What are the practices of 'living degrowth'?

The second aim of this paper is to look at the collected practices from a transformation perspective. As pointed out by degrowth scholars, transformation refers to "the need to go beyond pursuing or simply protesting against business-asusual to actively constituting new meanings and practices" (Asara et al. 2015, p. 379). Referring to this, we explore in which areas of life these new meanings and practices are situated, and look at what they aim to transform in broad terms. On a more theoretical level, our paper attempts to answer: how can living degrowth be conceptualized/understood as a transformative endeavour?

Before identifying and analysing the degrowth practices, the first section describes theoretical foundations of degrowth and practice theory and brings those together in a conceptual model. The second section gives an account of our methodology especially by focusing on applied theatre and performative methods. The third section examines the ways in which degrowth imaginaries are embodied in practices, as found through our empirical research. The paper concludes by interrogating the transformative characteristic of 'living degrowth'.

\section{Theoretical foundations}

\section{Degrowth: a radical proposal}

Degrowth calls for a society with a smaller metabolism, i.e. less production and consumption to reduce the overall throughput of energy and material in accordance with ecological limits. It poses a strong critique of economic growth, which is seen as highly problematic and causally related to both social and ecological crises (Demaria et al. 2013; Kallis et al. 2015). Degrowth also aims at "decolonizing" the public dialogue from economism and overcoming economic growth as a social objective by questioning the market-based relations in the society based on GDP and commodification (Fournier 2008; Kallis et al. 2015).

Thus, degrowth develops an alternative imaginary of an economy of care and commons, and endorses new forms of living and producing like eco-communities and cooperatives as well as policies for work sharing or basic and maximum income. Furthermore, it calls for equitably redistributing wealth both intra-generational (Global North and South) as well as inter-generational (current and future 
generations) and for a deepening of democracy (Demaria et al. 2013). Degrowth is a frame connecting multiple lines of thoughts and strategies by inviting proposals for a desired socio-ecological future motivated by social justice, democracy, respect for nature and its intrinsic value, meaning of life, well-being and anti-utilitarianism (Ibid).Critics of degrowth problematize these multiple policies and varieties of degrowth such as GDP degrowth, consumption degrowth or work-time degrowth and point out the social and political feasibility constraints and complexity of these proposals in achieving sustainability (Van den Bergh 2011). Recent movements such as the yellow vests illustrate the challenge of social-political acceptability of strict environmental regulation. Other scholars problematizes the 'quantitative' focus of degrowth and argue that qualitative aspects such as health, life expectancy, educational level have been neglected in the proposed transformations (Schwartzman 2012).

\section{Practice theory as a tool to frame degrowth practices towards sustainability}

In this article, we aim to understand the practices of degrowth by drawing upon the theory of practice and practice architectures. We use the following definition of practice:

A practice is a form of socially established cooperative human activity in which characteristic arrangements of actions and activities (doings) are comprehensible in terms of arrangements of relevant ideas in characteristic discourses (sayings), and when the people and objects involved are distributed in characteristic arrangements of relationships (relatings), and when this complex of sayings, doings and relatings 'hangs together' in a distinctive project. (Kemmis et al. 2014b, p. 31)

This definition points towards three characteristics of what constitutes a practice: (1) that it is composed of sayings, doings and relatings, which means that a practice is more than just people's actions, but also what they say and think to describe, interpret, explain, orient and justify the practice and how they relate to each other and the objects in the course of the practice; (2) and that sayings, doings and relatings have to "cohere with one another purposefully" in (3) the project of the practice, i.e. the distinctive aim which "is realized through the practice" (Kemmis et al. 2014a, pp. 52-53).

Practices at all levels are made possible by practice architectures. These are bundles of cultural-discursive, material-economic and social-political arrangements, which retain practices and provide diverse resources for their realization (Kemmis et al. 2014a). By extension, cultural-discursive arrangements provide language, ideas and discourses for the sayings of a practice, material-economic arrangements supply material resources (e.g. objects, physical spaces) for the doings of a practice, and social-political arrangements offer the social resources (e.g. specific relationships with people or objects) for the relatings of a practice (Kemmis et al. 2014a). Together, these arrangements and the resources they provide are called practice architectures, and are situated in sites such as everyday places like homes, schools or supermarkets. Practices and practice architectures are interdependent and mutually constitutive. Neither aspect dominates the other, nor can it exist without the other. On the one hand, practice architectures prefigure practices, on the other hand, practices can be rebuild by practitioners and change practice architectures.

\section{Living degrowth: a conceptual model}

The following model illustrates our theoretical understanding of the transformative ambition of degrowth by applying practice theory. It developed out of merging three streams of our inquiry: (1) the investigated content (degrowth, from an everyday perspective), (2) the ontological perspective (practice theory), and (3) the methodological approach (performative methods, hence looking at how degrowth is performed).

The model (see Fig. 1) is composed of four dimensions that we consider important in discussing living degrowth:

Individual highlighting the subjects who engage and act as agents of transformations; understanding their motivations, their (personal) struggles and what supports them.

Performative looking at practices (realized in distinctive sayings, doings and relatings), through which agents are active in the world and want to achieve transformations.

Collective seeing humans first and foremost as social beings, who are living and learning through participating in practices of social communities (Wenger 2009).

Structural acknowledging that subjects never conduct (transformative) actions in isolation, but in already existing sites which are constituted by cultural-discursive, material-economic and social-political arrangements (Kemmis et al. 2014a).

Living degrowth-conceptualized as a transformative endeavour with certain subjective, performative, collective and structural aspects-is related in our model to current problems and imagined futures. It appears as a bridge between the two, being both (1) a response to current problems of social inequality and ecological destruction and (2) an attempt to realize imagined futures of socio-ecological sustainability. Our research focused on the performative (i.e. practices) dimension, substantiating in which areas of life degrowth practices are situated and how they could be understood from a transformation perspective. 
Fig. 1 Conceptual model of living degrowth as an endeavour to transform current problems into imagined futures through individual, performative, collective and structural dimensions. Our own depiction, drawing upon practice theory by Kemmis et al. (2014a) and social learning theory by Wenger (2009)

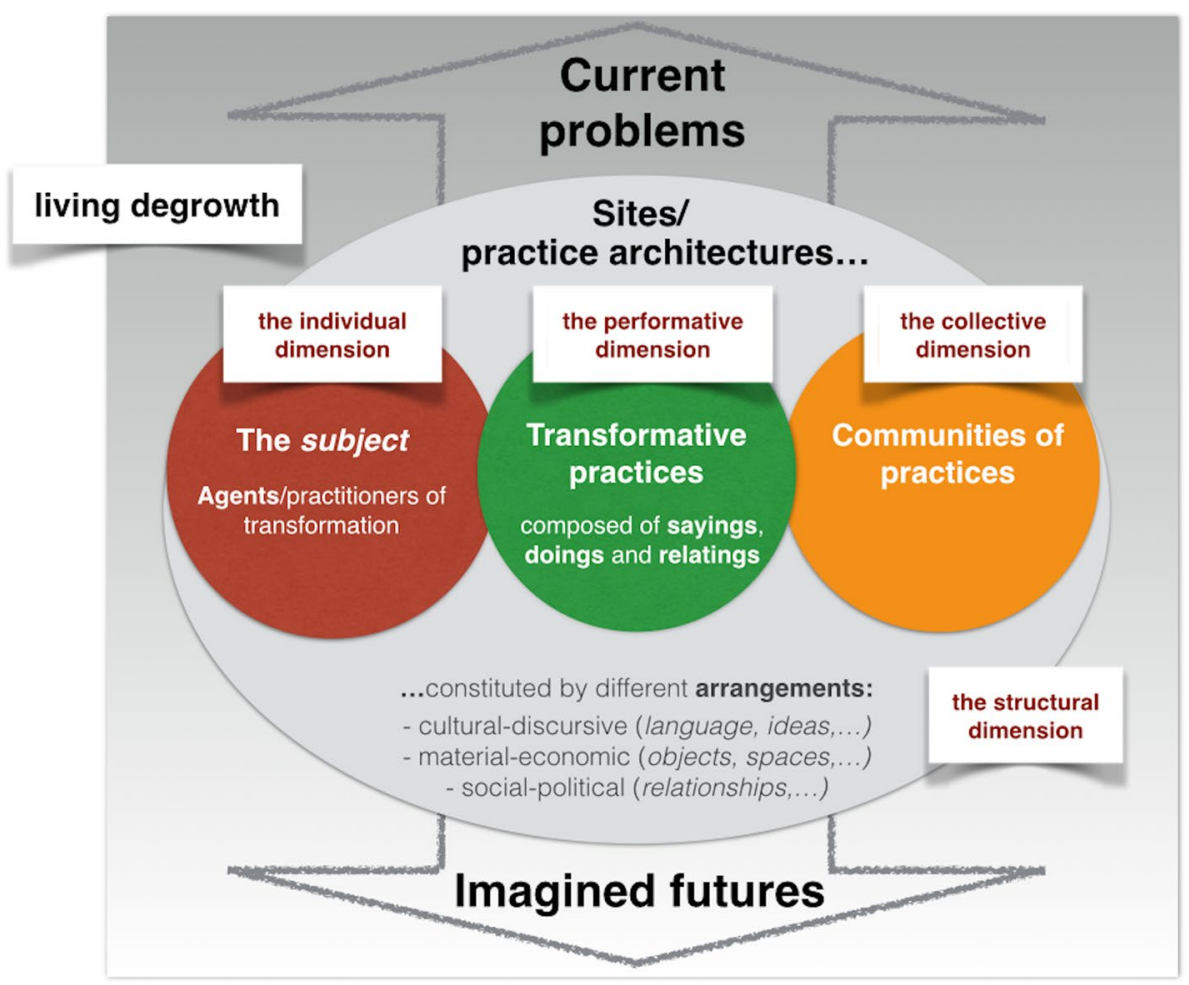

\section{Methodology: performative research}

As a methodology, we use performative methods, a concept recently introduced to sustainability science by Heras and Tàbara (2014: 388) and defined as:

a participatory form of integrative research aimed at integrating and combining elements from the performing arts into research in a flexible and context-specific manner within larger social and political processes, devised to support individual, community and institutional reflexivity and transformation.

Among performative methods, applied theatre is used to create more opportunities for exploration through performance or 'acting out' (Conrad 2004, p. 16). This is well fitting to the explorative nature of our research questions as it allows our informants to act out what living degrowth means, rather than only cognitively describing it. Applied theatre has, alongside other purposes, been used to approach diverse sustainability issues, including work on natural resource management in biosphere reserves (Heras and Tàbara 2016), environmental policy development (Guhrs et al. 2006), raising awareness about environmental resources or pollution (Metcalf and Veiga 2012) and sustainable energy development (Osnes 2013; Osnes et al. 2015). Diverse groups were addressed in these studies (including youth and women) and multiple environmental issues explored, indicating the flexibility of such methods. Hence, we see no general limitation to explore degrowth in a performative way. Furthermore, while several examples exist, as shown above, the use of applied theatre in environmental and sustainability sciences still remains one of the less explored (Heras and Tàbara 2014, p. 382). Accordingly, further exploring dramaturgical activities for sustainability research is a contribution to methodological development and diversity in this field.

Performative methods could support sustainability science through multiple functions (Heras and Tàbara 2014). A key function of performative activities is "integrating and embodying different kinds of knowledge, values and perspectives" (Heras and Tàbara 2014, p. 389). This is important to our research since degrowth is framed in this paper not only as an (academic) debate, but as a lived experience constituted by a range of practices. To explore these lived experiences, tapping into various forms of knowing (e.g. emotional, embodied, experiential, habitual) seems important as it can facilitate a powerful self-reflective process.

Self-reflection is not only needed to uncover and understand one's own practices, but feeds into broader, collective reflection processes. Performative methods can foster social reflexivity by creating a dramatic distance and safe space for discussing sensitive matters, furthermore they support the building and reconstructing of socio-ecological identities (Heras and Tàbara 2014). This matters because dealing with unsustainability requires more than increasing our knowledge: ultimately we need to answer the question "What role/s can I play?" (Heras and Tàbara 2014, p. 392) in supporting societal change. The described features of performative methods are relevant to our research, because 
they supported us in accessing (1) subjective accounts of degrowth and (2) transformative aspects of those.

\section{The theatre workshop in Barcelona}

For our empirical material, we applied performative methods during a 2-day theatre workshop in Barcelona in 2017. This became possible through the collaboration with the "young degrowth reading group" 2 and offered mutual benefits. The group had articulated their interest in engaging with degrowth through creative means, while we were looking for a suitable environment to gather empirical insights through performative methods. Most of the 13 participants $^{3}$ were (a) connected to academia, either through studies at master/ $\mathrm{PhD}$ level or (previous) academic work, and (b) involved in diverse forms of activism. This meant that participants were familiar with degrowth from an academic and activist perspective, legitimating their contribution to this study. Working with a group that had ties to academia biases the outcomes accordingly (e.g. use of complex terminology), but also ensured mutual understanding amongst participants and researchers and a certain level of consistency in the data.

The workshop was composed of various creative methods, mainly coming from Augusto Boal's theatre techniques called Theatre of the Oppressed (Boal 2008). An example of performative activities used was image theatre. This exercise, where participants created statues with their bodies, serves well to "explore symbolic language and mental representations" (Heras et al. 2016, p. 3) in response to a question/theme posed. Collecting data through performative methods, however, poses limitations due to the fact that participants need to familiarize themselves with creative and bodily ways of expression. We accounted for this by offering easy warm-up activities and designing the workshop from simple exercises in the beginning to more complex ones towards the end. Another limit of theatre methods is that they, while allowing for great explorative depth with emotional richness, sometimes make it difficult to gather a comprehensive overview over a broad topic. We balanced this out by incorporating reflection activities such as brainstorming or sharing in groups. In fact, an ongoing alternation of action and reflection is central to the Theatre of the Oppressed methodology (Fritz 2014). The activities (excluding breaks) summed up to $10 \mathrm{~h}$ of interaction, fairly equally split into exercises and reflections. The workshop yielded a substantial amount of various data, as described below. An

\footnotetext{
2 The group had formed 2016 in the social environment of ICTA, The Institute of Environmental Science and Technology at the Autonomous University of Barcelona (UAB).

${ }^{3}$ Participants were between 25 and 60 years old, 8 females, and 5 males. Most originated from European countries, but there was one each from India, Egypt and the US.
}

overview of activities can be found in Appendix 1, and the detailed script is provided in the Electronic Supplementary Material (S1).

\section{Complementary interviews}

To complement insights gathered through performative methods, we conducted three extensive semi-structured interviews with degrowth scholars (see Appendix 2).This can be understood as triangulation, because we used several methods and sources of data (Bryman 2008). The interviews focused on how well-known degrowth scholars view (their) degrowth practices, and served us to discuss initial results from the workshop. While such a triangulation does not "reveal "the whole picture"" (Silverman 2013, p. 138), it did yield additional valuable insights. Semi-structured interviews allowed to cover specific questions-prepared in advance (see interview guide in Appendix 3).

\section{Data analysis}

The workshop was documented using audio-, video- and photo-equipment and participants' notes from reflection/ brainstorming rounds. Interviews were audio recorded. Data analysis and interpretation was done using tools of grounded theory and thematic analysis.

The first step of structuring data took place already during the workshop: after participants had brainstormed and organized degrowth practices on cards, we did a first tentative coding - a central process in grounded theoryreviewing all cards and giving components of this data different "labels" (Bryman 2008, p. 542). We developed six preliminary headings that grouped practices and discussed those with the participants, who agreed and added one label. These seven labels (see Appendix 4) became themes for further analysis using a matrix, i.e. a "thematic framework [which] is used to classify and organize data according to key themes" (Ritchie et al. 2003, p. 220). This matrix, operationalized in a spreadsheet, included all sources of data (workshop activities and interviews) on one axis and the seven labels/key themes on the other axis (see S2). By filling in the matrix we got a general idea of the data, which lead us to identifying patterns in it and develop empirically grounded emergent categories (Williams 2012), which are presented hereafter.

\section{Living degrowth: an empirical account of degrowth practices}

This section presents the major findings of the empirical research by identifying degrowth practices. During the initial phase of analysing data, we used seven key themes, which we later condensed into five spheres of practices: (1) 
rethinking society, (2) acting political, (3) creating alternatives, (4) fostering connections, and (5) unveiling the self, with each sphere divided into several subcategories. In the following, we portray participants' own accounts of what living degrowth entails for them in terms of practices, i.e. we did not observe their practices in everyday life. Hence, we cannot testify to which extent those involved in our research only aspire or actually practice their depictions of living degrowth. However, our impression is that their depictions and reports are authentic, as they were filled with details, examples and emotions that can only stem from actual practice.

\section{Rethinking society}

Living degrowth seemed to be highly concerned with questioning and reimagining society. We grouped practices that specify this concern under the heading of rethinking society and present them in an order that makes narrative and procedural sense to us. Rethinking society entails observing and reflecting, which we see as good starting points for rigorously challenging existing orders. To use the words of a participant, it is important to "be honest and really observe the world [without] being dogmatic". Here we can imagine someone taking a step back to see oneself and the bigger picture in a non-judgemental way, becoming aware of what is actually happening. In a next step, by reflecting on values one can evaluate observations, which could help to "see contradictions" in and around us. A participant described how he observed many contradictions when thinking about implementing degrowth both on a personal and societal level. On the basis of observation and reflection, rethinking society needs questioning and deconstructing. Participants pointed to this repeatedly, arguing for the importance of "deconstructing currently present concepts" in our society. An example stressed was the need for a "radical critique of neoclassical economics", or for deconstructing concepts like "work". A participant showed deconstructing in a statue as a personal, inner process that was about challenging hegemonic ideas in society that had become "internalized structures" (see Fig. 2). In addition to the need of questioning broad or internalized concepts, deconstructing can also mean "questioning small micro-practices" in our everyday interactions.

Having taken (dominant) societal concepts apart, rethinking society means to imagine and construct alternatives. Participants argued for "envisioning/imagining utopia" and "constructing new alternatives" practically and theoretically. As an example, someone described that it was important for him to find "new orientations of lifestyles and life aims", asking questions like "Where do I/we want to go?" and "What do we want to reach?".

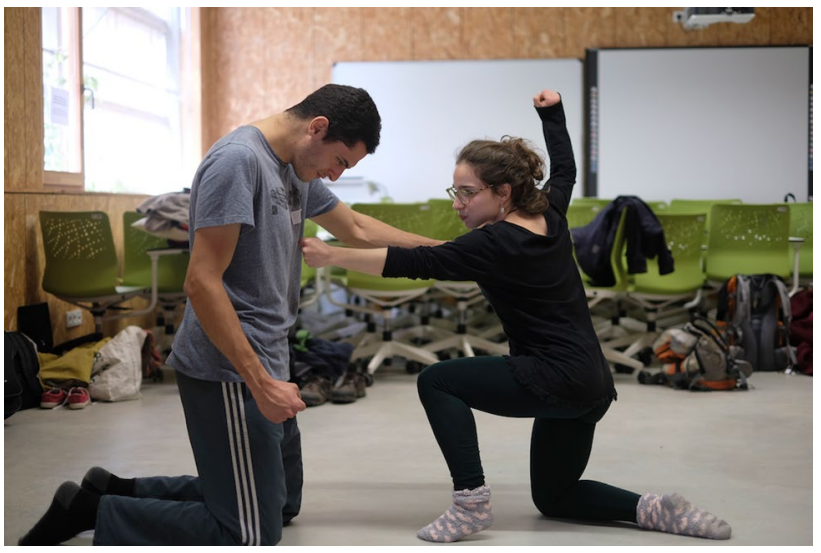

Fig. 2 A statue from the theatre workshop representing the struggle with "internalized structures"

The processes of imagining and constructing new ideas were, however, not seen as purely rational. A participant created a statue embodying "Thinking with the heart" as a favourite practice of living degrowth, showing the importance of connecting emotion and reason.

In the interviews, academic research and writing was discussed as a way of living degrowth. We see this very much as one (but not the only) way of rethinking society, combining many (or all) of the before mentioned practices. Academic practices related to degrowth were said to be underpinned by an especially critical attitude, both regarding the content of writing as well as by criticizing mainstream academic processes that put career considerations above quality of knowledge creation and social interactions. More cooperative and egalitarian procedures were discussed.

In all practices of rethinking society, learning and dialogue seem to play an important role. Practices of "knowing, reading and learning more" or non-hierarchical education support a questioning of society, as "discussing and debating" (for example "to break the hegemony of growth") also do.

Demaria et al. (2013) portray "academic and non-academic research" as a degrowth strategy and D'Alisa and Kallis (2015) discuss the relevance of post-normal science for a degrowth transition. Post-normal science calls for extended peer communities, i.e. a democratisation of science, to effectively deal with global environmental challenges (Funtowicz and Ravetz 1993). These references point out that rethinking society needs science, but in a mode that creates "cooperative research by bringing together scientists, practitioners and activists", something the degrowth conferences strive for Demaria et al. (2013, p. 204).

Looking at the potential of this practice sphere in regard to transformations, we argue that it wrestles with dominant social ideas, principles and discourses and their constituting processes. Put differently, the described practices of 
rethinking society are vital for transforming the cultural-discursive space in society.

\section{Acting political}

Empirically, we grouped practices referring to processes and actions that are concerned with public opinions and collective decisions under the heading of acting political. However, participants acknowledged-and so do we-that "we act politically all the time", embracing the feminist claim that "the personal is political".

A central part of political engagement is advocating for certain ideas, such as "practices related to defending degrowth in public". Participants were concerned with passing the degrowth message to others, and how to reach specific groups like workers or ethnic minorities. They highlighted the need to invite others to join the conversation about degrowth and to find "different ways of communication". The already quoted necessity for "discussing and debating to break the hegemony of growth" can here be seen as a way of advocating growth critique. If we see advocating more broadly as the way that people share knowledge, then it relates to ideas and practices of open source, digital commons and creative commons licenses.

While we understand advocating as primarily discursive practices, we use resisting to refer to political practices of a contentious nature (Tarrow 2011). General insights from our data describe it as intervening politically or violating the accepted order. Resistance can occur "in different types and from different levels". As different types, participants referred to and portrayed both more common ways of resistance-marching and protesting — and discussed the less common happenings of "direct action resistance" (described as "stopping bad industrial operations and unsustainable activities directly") and "occupation movements". The latter has both a component of resisting by occupying spaces (e.g. houses, squares), but also of creating alternatives. Regarding resistance from different levels, we found references to geographical space — neighbourhood, local or city level—and a reference to the non-physical space of media, where a participant described the practice of challenging fake news. Most or all of these practices can be seen as contentious politics in the sense that they are carried out by collective actors in confrontation with elites, authorities, and opponents around their claims (Tarrow 2011).

Underpinning the aforementioned political activities as well as many other practices of living degrowth, we found organizing as a highly political practice in itself. For individuals, it means participating and getting involved in more than individual action, i.e. in "collective action". For groups, it means to guide themselves and their organizations according to principles such as collaboration, cooperation, horizontality and sovereignty, which were stressed by participants and scholars in the context of degrowth. The emphasis on collective organizing seems to us closely related to striving for non-hierarchical structures/processes, especially seeking consensus in decision making. As we show later, practices of organizing are strongly related to the role community plays in living degrowth.

Acting political refers to practices of advocating degrowth discursively, resisting developments that-from a degrowth perspective-are unfavourable through contentious politics and pursuing common goals through collective, cooperative organizing. Resisting especially appears prominently in degrowth literature, for example in "oppositional activism" (Demaria et al. 2013), civil disobedience (Renou 2015) and the Indignados or Occupy movement, which also has a strong component of collective organizing and advocating, e.g. for "systemic change" (Asara and Muraca 2015, p. 171). Advocating can also take place within existing institutions, as Demaria et al. (2013) show by discussing reformism as a degrowth strategy and digital commons are considered as a way to distribute information horizontally (Fuster Morell 2015).

From a transformation perspective, we suggest to look at this sphere of practices as intervening in processes of social and political choice in society in favour of degrowth objectives. Furthermore, these practices aim at strengthening or establishing more democratic political processes themselves. In other words, these practices are crucial for transforming the contents and processes of decision making, i.e. the collective social-political space(s) at different levels.

\section{Creating alternatives}

Under creating alternatives, we describe practices of consuming consciously and less, sharing in manifold ways, alternative mobility patterns, sourcing and consuming food ethically, doing things yourself and producing cooperatively as practices that create alternative lifestyles and structures. These practices are mirrored in the degrowth strategy of "building alternatives" (Demaria et al. 2013, p. 202) or Carlsson's concept of Nowtopians (2015).

A reoccurring term regarding consumption and personal activities was consciousness. In the words of one of the scholars, this appears as "being conscious of the impact of your acts", which she related to the environmental and social impacts of consumption, travel or services. This consciousness can also be taken further, as one of the participants noticed, to an awareness of "consumerism" and "commodification" more generally. Practices that express such consciousness were described as informing yourself, making informed decisions and thinking about one's real needs. We interpret this as the awareness that needs can also be created, as degrowth thinker Latouche (2009) for instance discussed. Guided by a mind set of "less means more", these 
practices support a habit of consuming less and forsaking certain behaviours/goods. Examples included not needing "to be technologically updated" or "trying to waste less" and reducing/avoiding plastic consumption.

Participants discussed practices of sharing, which similarly to being conscious appeared as a cross-cutting activity, i.e. relevant to many areas of life. Sharing could be practiced regarding "anything, from living space to food, to clothes, to help", as a participant explained. Someone expressed this in the common saying, "sharing is caring". Sharing does not only apply to material goods, but can also be practiced through exchanging skills, which was mentioned in connection to ideas of a gift economy. Furthermore, the practices of open access, open source and digital commons described before represent a way of sharing knowledge and technology.

Mobility was one of the areas about which participants and scholars showed great awareness. Often mentioned and discussed was the practice of flying less, but also travelling less in general or travelling slow, for example by train. In one of the improvisation exercises during the workshop, some participants played a scene of sharing a car, which could also have been interpreted as some kind of sharing economy or public transport. Both during discussion and theatre exercises, cycling was a prominent practice. It was portrayed twice as a favourite practice of living degrowth, and described as "regenerating".

A range of practices surrounded the ethical sourcing and consuming of food. Participants highlighted the importance of consuming local food, preferably vegetarian and/or ecologically produced. Practices of producing/sourcing such food were participating in food cooperatives, producing food yourself (e.g. in a vegetable garden) or the extensive practice of agroecology. Another food type and practice described was recycling food, for example through food saving initiatives. Two other types of food were discussed and portrayed: Picking and using wild plants, fruits and berries and "eating only wild- or free-range meat animal products"; the latter could be sourced through practices of "hunting and fishing" yourself. Moving to how food is made and consumed, participants described processing food yourself (producing homemade food, such as bread, pasta or tomato sauce) and cooking yourself, even by experimenting with solar ovens. Sharing food and eating together were mentioned as personally enriching practices, as was "eating in reasonable quantities".

Another set of practices alternative to mainstream consumerism reflect a DIY (do-it-yourself) mentality. Many of them can be seen as experimenting with low impact lifestyles. Those that appear to us as more common ones included repairing things yourself, for example bikes, sewing or fixing clothes, or upcycling old/waste materials into new things. Practices that we find less common in our societies are trying to live without electrical household devices, or building houses yourself. Some of the practices mentioned before intersect in "autogestiò", a term a participant used to refer to a complex practice of self-management that appears as "do-it-yourself local empowerment" (de la Pena 2013, p. 11).

Practices that were less prominent in the workshop and interviews, but nevertheless mentioned, are related to producing cooperatively. Food cooperatives were mentioned and one participant brought up the concept of "cooperativism", which refers to collectively owning and democratically running the means of production (Ratner 2009). Likewise, a scholar discussed consumer and energy cooperatives as emerging "in the alternative social and solidarity economy networks".

However, when reflecting upon this sphere we realize that the emphasis was always on very small-scale, local practices. More complex attempts like alternative banks (Demaria et al. 2013) or community currencies (Dittmer 2015) were missing. Furthermore, when discussing key themes from the workshop with the scholars, one of them pointed out that "reproductivity" was missing. This feminist term, synonymous to care work, describes all practices that reproduce life from a social point of view, such as "child rearing, taking care of the sick and the elderly, education, health care and social provisioning" (Bauhardt 2014, p. 62). During the workshop, the word care was used, but more broadly in the sense of an attitude of care and taking care for oneself, each other and the world. We decided to include reproductivity in our summarizing concept of living degrowth.

Looking at this practice sphere in regard to transformations, we suggest to see it as targeting the productive and reproductive processes and structures in society. Hence, these practices hold a key role in transforming the material-economic dimension of individual and collective life.

\section{Fostering connections}

Under fostering connections, we grouped practices that are essentially about relationships. A fundamental element of this sphere is cultivating interpersonal relationships. This meant for a participant enjoying and fostering them, e.g. by drinking beer with friends, but also through travelling to reconnect with loved ones. Participants vividly discussed personal conflicts between taking care of relationships and unsustainable mobility patterns. Living degrowth is, however, not only about having relationships, but it "can express itself in the way you build relationships with others", in the "quality of the relations between the people [and] the quality of our interactions". Practices that are describing this quality and way of relating were being empathic, showing appreciation and listening and communicating in different ways, which can be summarized in the attitude of care. An example from academia was establishing caring professional 
relationships with authors of a journal, e.g. through giving constructive feedback.

Ideas and practices connected to community are distinctive in our research. To use the words of a participant: "Degrowth is about cooperation, [and] community". One of our informants explained how "it is very hard to have most of these [degrowth] practices without a community support", e.g. a food cooperative. Our insights suggest that communities, just like relationships, need to be nourished to have certain qualities. Practices for nourishing community were described broadly as "caring for our community", for example by "taking care of the emotional harmony, managing the emotions within a group, dealing with all that emerges". Similarly, another informant said it was about "trying to make others comfortable" and having "a good time together". Other ways of nourishing community can be "caring more for each other and the common needs" than for individual needs, but also to "improve myself to improve the community". Concrete examples of community were the practices of living collectively and collective organizing. Participants clearly enjoyed improvising around the theme of "living community". The improvisation exercise led to a figure where all participants positioned themselves in concentric circles with connected hands. To us, this symbolized that enjoyable communities are highly interconnected with circular, horizontal structures, and that members need to take efforts to make things work.

Two more community-related themes appeared: first, the importance of diversity was emphasized. Considering, valuing and strengthening cultural diversity were suggested as important practices related to degrowth. Second, one of the scholars argued that community plays a central role in finding meaning of life through collective dépense. He described latter as spending the socially accumulated surplus in ways that create meaning "beyond the mere survival" of the people who participate in it. One simple example of collective dépense coming from the past is the carnival. ${ }^{4}$

Apart from fostering connections amongst humans, connecting with nature also appeared. Participants described "enjoying intimate connection with nature and the more-than human world" and "being in nature" as practices. Some of their favourite degrowth practices were nature related, e.g. climbing, or cycling (poetically described as "Fly[ing] with the wind"). Another statue symbolized the connection with nature very figuratively in the message "I am attached to the Earth". In contrast, developing "ecosystem understanding" sounds less effective, but was also described as important to connect with nature. As a heading for these practices, a participant suggested the phrase "decentring the human",

\footnotetext{
${ }^{4}$ A more detailed description of the complex concept of dépense can be found in Romano (2015)
}

meaning that while most other practices were centred around the human, he saw degrowth also about considering the "more-than human world".

Fostering connections as a sphere of degrowth practices that cultivate interpersonal relationships, nourish community, and focus on connecting with nature. In recent degrowth literature "responsible togetherness" and a "harmonious relationship with nature and the earth" have been highlighted (Natale et al. 2016, pp. 51-53). Also, Cattaneo (2015) describes ecocommunities as degrowth manifestations, which take many different forms but are usually characterized by an ecological and a social, i.e. community dimension. In contrast to these general descriptions, our research offered more subjective accounts of the high relevance of connections.

Regarding the transformative potential of this practice sphere, we interpret it as drawing attention to the relational aspects of life. Put differently, these practices are vital for transforming interpersonal relationships, communities and humans place in nature.

\section{Unveiling the self}

As has become clear during our research, living degrowth does not only entail practices that are oriented outwards (through social, political, intellectual or material interactions), but also practices concerned with the inner world, i.e. the individual self. These practices are manifold and potentially contradicting in the way they depict the human self and its importance. With unveiling the self, we thus tried to find a neutral heading for these practices, one that does not foreclose how or why people engage with their selves. However, this heading is not absolutely neutral, as it points towards the need to draw focus to the self to understand what living degrowth means.

The ability and practice of knowing yourself or being self-aware seem to play a crucial role for living degrowth, probably feeding into many other practices. A participant mentioned the practice of "thinking about my real needs", which could help to become aware of what matters to oneself. This self-awareness could be seen as a precondition for what one of our informants described as "having minimal compromises with myself". Ultimately, knowing one's needs and values seems essential to promote well-being.

In fact, well-being and happiness mattered to most participants, or to use a quote: "living well and having a good, and probably joyful life". We use well-being and happiness here interchangeably, including the understanding of "happiness in a sense of meaningfulness". The practices that help people in fostering well-being seem to vary widely, including practices from all described spheres of living degrowth (and beyond). One participant explained that focusing on wellbeing could be done for instance through "personal growth, arts, sports, nature". While acknowledging these various 
ways, we see one practice that could have an over-arching nature-finding balance. People noted balancing work/life or working less and a scholar described the wish to balance life in terms of having space for intellectual, political and practical work. Living degrowth for some participants was connected to practices of being mindful, described in several ways. First, it means "focusing on just one thing at the time" and living more presently; second, it has a time component, as in "taking time to do things" and "living more slowly"; and a third aspect is simply doing less. An aim well in line with these practices is to "make it simple". Participants mentioned "meditation" and "mindfulness" as supporting practices for being mindful. Similarly, Wamsler et al. (2017) recently argued for the importance of mindfulness in facilitating sustainability.

Interestingly enough, artistic practices were suggested as part of living degrowth. Indeed, one of the scholars even named the arts as one out of four areas that she considered key for living degrowth, next to intellectual, political and practical activities. She described them as "non-utilitarian, non-rational type of activities", such as drawing, painting, making music and dancing, which were "inspiring" action and bringing an "emotional and motivational component" to degrowth projects. Participants also discussed creativity/arts in connection to degrowth. Living degrowth to some means considering the body. One of the participants specifically described "enjoy being in a body" as a practice. This made us reflect and notice how, although the body is essential for experiencing the world, it was not a conscious or outspoken target of many practices discussed so far. Regardless, our observations of improvisation activities during the workshop give reason to claim that participants enjoy their bodies through diverse practices. When asked to improvise practices that foster well-being, participants were dancing, playing around, exercising their bodies, massaging each other, meditating and laying relaxed on the ground, all practices that arguably create pleasant bodily sensations.

The above self-related practices we discussed so far might appear as oriented towards pleasant experiences, happiness and positivity. However, our research suggests that living degrowth is also about facing and unveiling unpleasant (inner) experiences and putting "the vulnerability of life at the centre of a degrowth society". A general practice in this regard was described by a scholar as "presenting the complexity of each personality", pointing towards the need of speaking about "vulnerability", presenting "our uncertainty", "our dark side", "our inability" and "our negativity". This is important to reverse "the idea of self-promotion, [which lies] at the core of the growth society we live in". He described self-promotion as the attitude and need "to be good, to sell yourself as a fit, smart, rational, polite, civil" person to successfully inhabit growth society. However, this "anthropological subject" produced by western, modern, industrial societies should be problematized. Indeed, self-promotion and the liberation of "all the potentiality each subject has" to "find its meaning of life" are the fundamental points that justify "the right to mobilize all the resources that one thinks are useful and necessary in order to unveil all the potentiality of this self". The scholar argued that this self-promotional narrative is key to understand why western societies mobilize so many material resources at societal level. By rejecting self-promotion and aspiring "to create an anthropology of absence", i.e. "to be forgotten", the push towards the mobilization of resource will deflate.

Brought forward by another scholar, related to being vulnerable, are practices of "learning to deal with inner conflicts" and "learning to deal with challenges". They appear as an answer to the experience of conflicts, challenges and contradictions that seem to be inevitable parts of living degrowth. One way of dealing with contradictions for instance is to integrate them by acknowledging that "when we face a contradiction, we have (...) polar sides inside of us". By not rejecting or oppressing any of the positions one might become able "to act from a different position" and in a wiser way.

In short, we portrayed different practices around the self such as being self-aware and fostering well-being, being mindful, practicing arts and enjoying the body, showing vulnerability, rejecting self-promotion and facing conflicts. In the prominent degrowth literature, such practices are hardly visible. Well-being is clearly discussed by authors like Demaria et al. (2013) and Sekulova (2015), but we did not find references for practices concerning creativity, mindfulness, the body or conflicts/challenges. Here our research suggests that degrowth literature needs to recognize and discuss practices related to the self more prominently. This suggestion aligns well with the more general analysis that "sustainability science has neglected an important dimension of human experience-the inner worlds of individuals" and the call for their recognition in future research and practice (Ives et al. 2019). Our research also brings forward some questions for this discussion. Depending on how we interpret and orient practices related to inner worlds, they can support or contradict each other. For example, how does rejecting self-promotion relate to fostering well-being?

Looking at this sphere of practices from a transformation perspective, we see it as dealing with the self and related conceptions. In other words, these practices could play an essential role in transforming identities and concepts of self that are conducive to transformations in other spheres of life.

\section{Spheres of practices in living degrowth}

The five spheres of practices and their subcategories are summarized in Fig. 3. We included guiding ideas, aims, values or principles mentioned during the workshop and interviews. They can be understood as sayings, i.e. the language 
Fig. 3 A preliminary account of practices of living degrowth, grouped into five spheres of practices and their subcategories (green field). These practices are guided by ideas and principles (blue field). (Own graphic)

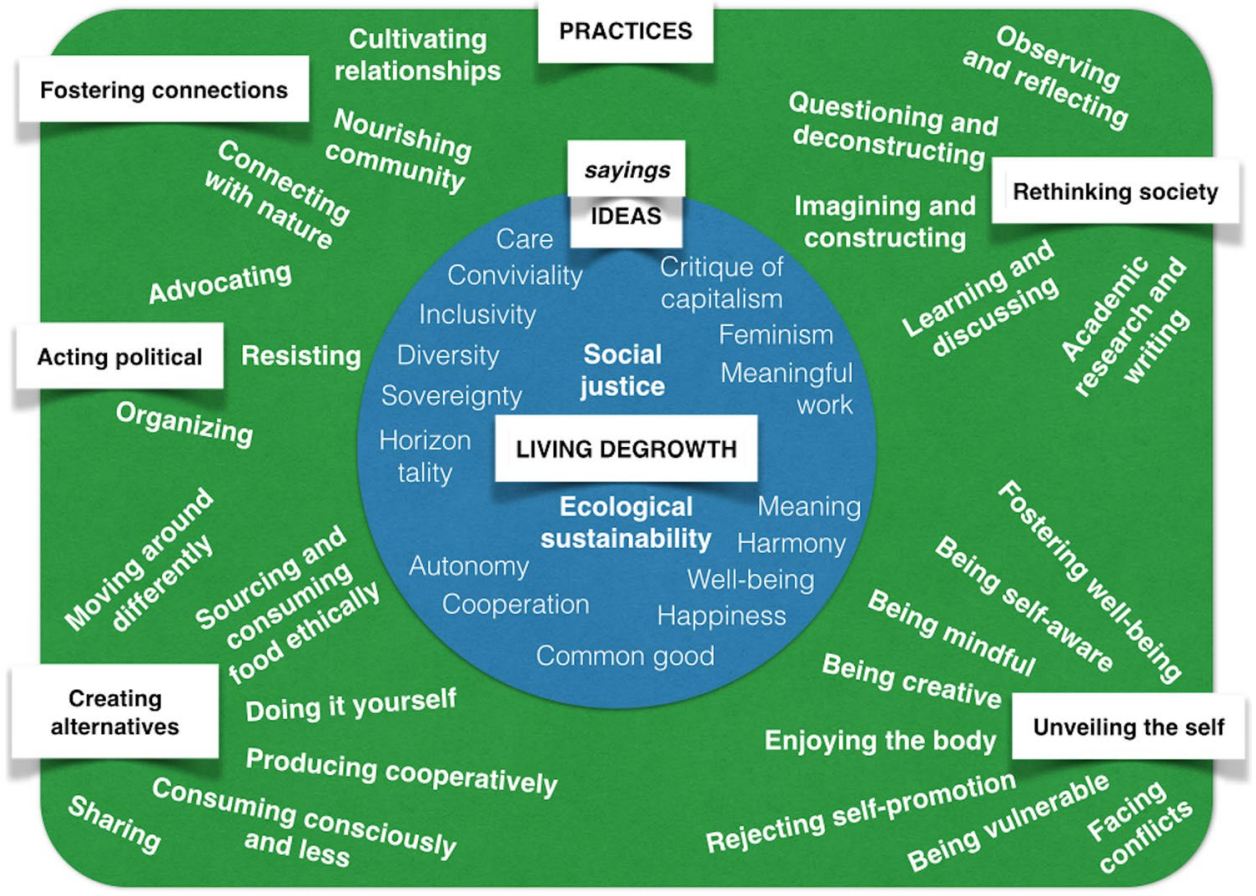

and discourses used to comprehend, justify and orient the practices of living degrowth (Kemmis et al. 2014b). While our research did not explicitly focus on how these practices are interlinked, they appeared as highly interconnected and in many ways mutually supportive. Further research could reveal these linkages and their meanings.

Clearly, most of the practices we described are not unique to the degrowth community, but rather shared with many other social movements related to sustainability and social justice, and some practices are even widely spread in western societies without any connection to these movements. To us, this is not a limitation, but a chance for the degrowth movement to reach out and show others that what they already do could potentially be in favour of degrowth transformations. However, our research is a preliminary, non-exhaustive compilation that is shaped by academically trained participants and a predominantly European perspective. We encourage other researchers to ask similar questions with other participants to fill existing gaps and further the understanding of degrowth practices.

\section{Realms of transformation in living degrowth}

After having offered a preliminary account of degrowth through a subjective perspective and a practice lens, we want to conclude by merging these empirical findings with our conceptual model (Fig. 1). This helps us to further develop the conceptualisation of living degrowth as a transformative endeavour.
Building on our findings, we take a general look at the broad aspects of life these degrowth practices are engaging with and aim to transform. We argue that living degrowth is not only concerned with five spheres of practices, but that these five spheres serve as a useful basis to conceptualize five realms of "What needs to be transformed?". We also suggest that we can understand the processes of transformations as finding new and different answers to five guiding questions. We argue that people engaged in degrowth perform.

(a) Practices of rethinking society, thus striving to transform ideas, principles and discourses in our society, guided by the question "How do we understand the world and how do we want it to be in an imagined future?".

(b) Practices of acting political, thus aiming to transform processes of social/political choice, guided by the question "How do we collectively decide on and bring about what we want (and what not) for an imagined future?".

(c) Practices of creating alternatives, thus pursuing transformations of re/productive structures and processes, guided by the question "How do we provide for our needs enabling an imagined future?".

(d) Practices of fostering connections, thus seeking to transform interpersonal relationships, communities and humans' place in nature, guided by the question "How do we relate to each other and the more-than-human world to support an imagined future?". 


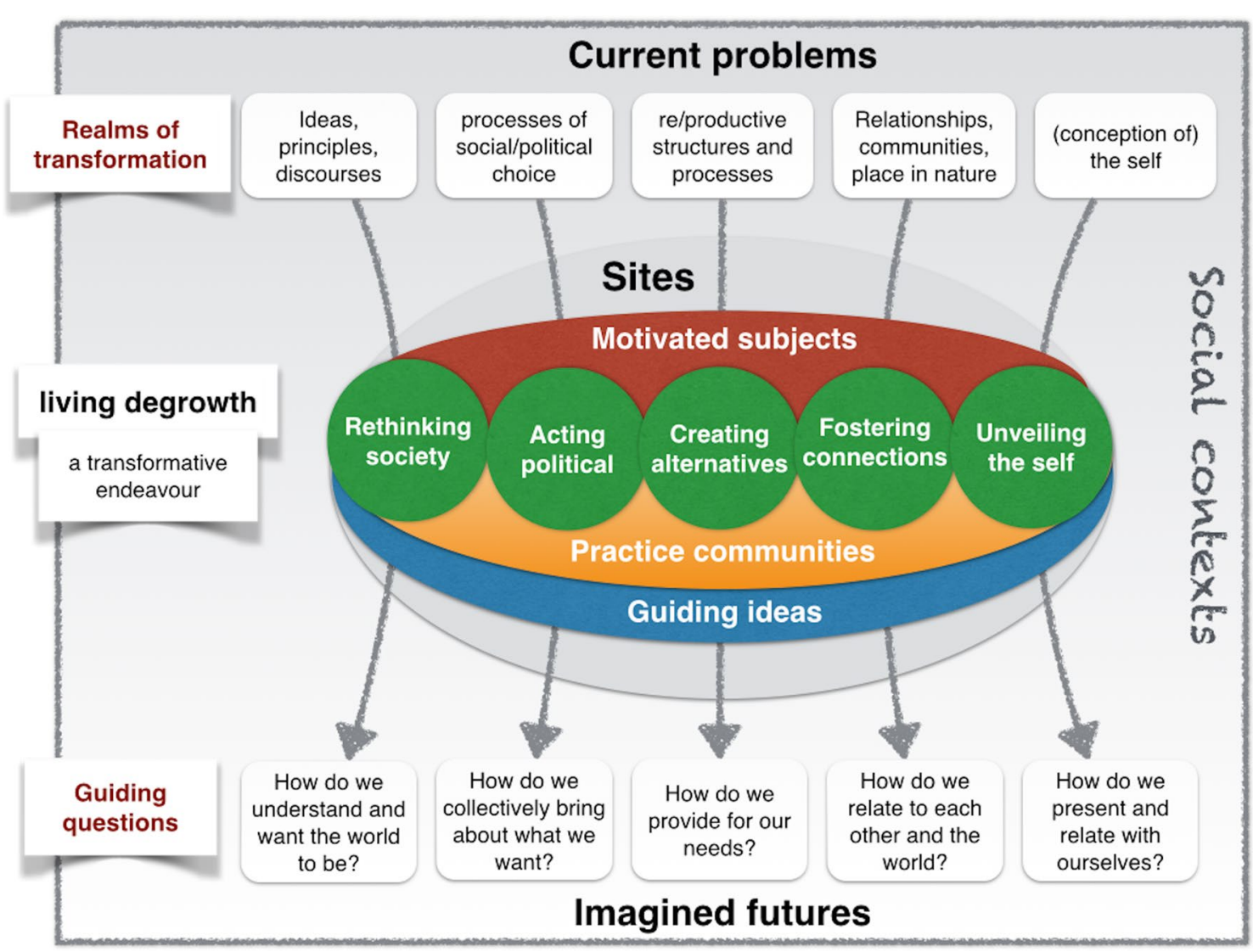

Fig. 4 Living degrowth as a transformative endeavour, portraying five realms of transformation with related practice spheres and guiding questions (own graphic)

(e) Practices of unveiling the self, thus potentially transforming (our conception of) the self, guided by the question "How do we present and relate with ourselves allowing for an imagined future?".

Following this train of thought we conceptualize living degrowth as depicted in Fig. 4.

The figure is build around the five spheres of practices that we discovered through our research. We suggest that these practice spheres are aiming to transform current problems, presented in five realms in the top of the graphic. The practices can be seen as guided by questions (at the bottom of the graphic) that are/need to be answered in new/different ways to realize imagined futures. The practices of living degrowth are carried out by motivated subjects/agents and connected in practice communities. Practices, agents and communities are oriented by a set of guiding ideas, in which social justice and ecological sustainability form the core. All this together is embedded in particular sites, as well as in broader social contexts.

By looking at our findings in this general way, we argue that the stated realms and described practices reach from the outer to the inner and vice versa-touching upon theoretical, discursive, political, material, economic, social and personal dimensions of world and life. Relating this back to debates about transformation we claim that degrowth practices in their collectivity seem to aim for comprehensive, substantial and profound changes across multiple dimensions and scales, as O'Brien (2012) called for. This orientation towards radical, systemic and holistic change encourages us to claim that degrowth not only in theory, but also in practice carries forward its transformative ambition and nature. This might not come as a surprise to those familiar with degrowth literature, as it continuously calls for deliberate transformative change (e. g. Asara et al. 2015). We see our contribution here in illuminating how the degrowth vocabulary is interpreted by individual agents regarding their everyday lives.

\section{Conclusion}

This paper contributes to the field of degrowth in the context of sustainability science in several ways. By applying performative methods, we made use of an innovative methodological approach in sustainability science, which allowed for a meaningful integration of various sources of 
knowledge and judgement, in combination with emotionrich expressions and affective communication. By putting forward the idea of living degrowth, we investigated degrowth's large array of concerns, goals, strategies and actions as lived experiences. The resulting preliminary account of living degrowth offered in this article may provide orientation for "what is to be done?" in a way that makes degrowth thinking more accessible and applicable to everyday life without loosing its intriguing complexity. Also, we explore degrowth from a subjective perspective through participatory and innovative methods as we attempt to open new spaces of investigation. Through this opening degrowth appeared relevant beyond an academic debate or realm of activism into the intimate spheres of relationships, individual life paths and conceptions of self. In this sense, our paper recognizes, reveals and supports the crucial role that people's inner worlds play in the context of sustainability science and practice. By showing this wide range of practices connected to degrowth—bridging the inner and outer-we hope to contribute to overcoming narrow, one-sided either/or approaches to what needs to be done and to what degrowth means, as diverse strategies can be compatible and important for transformations. The question 'What role can I play in this future?' can thus be answered in manifold individually appealing and meaningful ways, hopefully encouraging more people to see their role in bringing about imagined futures. Lastly, by relating practice theory to degrowth, we highlight in this paper that for transforming our world, we need to transform our practices and the practice architectures that hold them in place.

Acknowledgements Open access funding provided by Lund University. Thanks to Benno Zenker for co-creating and co-facilitating the research-oriented and theatre-based participatory workshop on degrowth in Barcelona. Fulvia Ferri and Jolanda Iserlohn are thanked for enabling the collaboration with the young degrowth reading group. We also want to thank the participants of the theatre-workshop for their time, interest and sharing of personal stories. Likewise we thank Ekaterina Chertkovskaya, Filka Sekulova and Giacomo D'Alisa for the enriching interviews. Further we want to acknowledge Heidi Hendersson, Ines Omann, David Tabara as well as two anonymous reviewers for their support during the writing process.

Open Access This article is distributed under the terms of the Creative Commons Attribution 4.0 International License (http://creativeco mmons.org/licenses/by/4.0/), which permits unrestricted use, distribution, and reproduction in any medium, provided you give appropriate credit to the original author(s) and the source, provide a link to the Creative Commons license, and indicate if changes were made.

\section{References}

Asara V, Muraca B (2015) Indignados (Occupy). In: D'Alisa G, Demaria F, Kallis G (eds) Degrowth: a vocabulary for a new era. Routledge, Abingdon, pp 169-171
Asara V, Otero I, Demaria F, Corbera E (2015) Socially sustainable degrowth as a social-ecological transformation: repoliticizing sustainability. Sustain Sci 10(3):375-384. https://doi. org/10.1007/s11625-015-0321-9

Bauhardt C (2014) Solutions to the crisis? The green new deal, degrowth, and the solidarity economy: alternatives to the capitalist growth economy from an ecofeminist economics perspective. Ecol Econ 102:60-68. https://doi.org/10.1016/j.ecole con.2014.03.015

Blühdorn I (2007) Sustaining the unsustainable: Symbolic politics and the politics of simulation. Environ Polit 16(2):251-275. https://doi.org/10.1080/09644010701211759

Boal A (2008) Theatre of the oppressed (get political). Pluto Press, London

Brown K, O’Neill S, Fabricius C (2013) Social science understandings of transformations. In: ISSC, UNESCO (eds) World social science report 2013: changing global environments, OECD Publishing, UNESCO Publishing, Paris, pp 100-106

Bryman A (2008) Social research methods. Oxford University Press, Oxford

Carlsson C (2015) Nowtopians. In: D’Alisa G, Demaria F, Kallis G (eds) Degrowth: a vocabulary for a new era. Routledge, Abingdon, pp 182-184

Cattaneo C (2015) Eco-Communities. In: D’Alisa G, Demaria F, Kallis G (eds) Degrowth: a vocabulary for a new era. Routledge, Abingdon, pp 165-168

Conrad D (2004) Exploring risky youth experiences: popular theatre as a participatory, performative research method. Int J Qual Methods 3(1):12-25. https://doi.org/10.1177/160940690400300102

D’Alisa G, Kallis G (2015) Post-Normal Science. In: D'Alisa G, Demaria F, Kallis G (eds) Degrowth: a vocabulary for a new era. Routledge, Abingdon, pp 185-188

De la Pena DS (2013) Experiments in Participatory Urbanism: Reform and Autogestión as Emerging Forms of Urban Activism in Barcelona (Doctor of Philosophy Dissertation) University of California, Berkeley

Demaria F, Schneider F, Sekulova F, Martinez-Alier J (2013) What is degrowth? From an activist slogan to a social movement. Environ Values 22(2):191-215

Díaz S, Settele J, Brondízio ES, Ngo HT (eds) (2019) Summary for policymakers of the global assessment report on biodiversity and ecosystem services of the Intergovernmental Science-Policy Platform on Biodiversity and Ecosystem Services. IPBES secretariat, Bonn

Dittmer K (2015) Community Currencies. In: D'Alisa G, Demaria F, Kallis G (eds) Degrowth: a vocabulary for a new era. Routledge, Abingdon, pp 149-151

Flipo F, Schneider F (2015) Foreword. In: D'Alisa G, Demaria F, Kallis G (eds) Degrowth: a vocabulary for a new era. Routledge, Abingdon, pp xxiii-xxvi

Fournier V (2008) Escaping from the economy: the politics of degrowth. Int J Sociol Soc Pol 28(11/12):528-545. https://doi. org/10.1108/01443330810915233

Fritz B (2014) InExActArt - the autopoietic theatre of augusto boal: a handbook of theatre of the oppressed practice. Ibidem-Verlag, Stuttgart

Funtowicz SO, Ravetz JR (1993) Science for the post-normal age. Futures 25:739-755. https://doi.org/10.1016/0016-3287(93)90022 $-\mathrm{L}$

Fuster Morell M (2015) Digital commons. In: D’Alisa G, Demaria F, Kallis G (eds) Degrowth: a vocabulary for a new era. Routledge, Abingdon, pp 159-161

Guhrs T, Rihoy L, Guhrs M (2006) Using theatre in participatory environmental policy making. Particip Learn Action 55:87-93 
Heras M, Tàbara JD (2014) Let's play transformations! Performative methods for sustainability. Sustain Sci 9(3):379-398. https://doi. org/10.1007/s11625-014-0245-9

Heras M, Tàbara JD (2016) Conservation theatre: mirroring experiences and performing stories in community management of natural resources. Soc Nat Resour 29(8):948-964. https://doi. org/10.1080/08941920.2015.1095375

Heras M, Tàbara JD, Meza A (2016) Performing biospheric futures with younger generations: a case in the MAB Reserve of $\mathrm{La}$ Sepultura, Mexico. Ecol Soc 21(2):14. https://doi.org/10.5751/ ES-08317-210214

Ives CD, Freeth R, Fischer J (2019) Inside-out sustainability: the neglect of inner worlds. Ambio. https://doi.org/10.1007/s 1328 0-019-01187-w

Kallis G, Demaria F, D'Alisa G (2015) Introduction: degrowth. In: D'Alisa G, Demaria F, Kallis G (eds) Degrowth: a vocabulary for a new era. Routledge, Abingdon, pp 1-17

Kemmis S, McTaggart R, Nixon R (2014a) The Action research planner: doing critical participatory action research. Springer, Singapore

Kemmis S, Wilkinson J, Edwards-Groves C, Hardy I, Grootenboer P, Bristol L (2014b) Changing practices, changing education. Springer, Singapore

Latouche S (2009) Farewell to growth. Polity, Cambridge

Meadows DH (1972) The limits to growth : a report for the Club of Rome's project on the predicament of mankind. Universe Books, New York

Metcalf SM, Veiga MM (2012) Using street theatre to increase awareness of and reduce mercury pollution in the artisanal gold mining sector: a case from Zimbabwe. J Clean Prod 37:179-184. https:// doi.org/10.1016/j.jclepro.2012.07.004

Natale A, Di Martino S, Procentese F, Arcidiacono C (2016) Degrowth and critical community psychology: contributions towards individual and social well-being. Futures 78-79:47-56. https:// doi.org/10.1016/j.futures.2016.03.020

O'Brien K (2012) Global environmental change II: from adaptation to deliberate transformation. Prog Hum Geogr 36(5):667-676

Osnes B (2013) Engaging women's voices through theatre for energy development. Renew Energy 49:185-187. https://doi. org/10.1016/j.renene.2012.01.036

Osnes B, Weitkamp L, Manygoats A (2015) A framework for engaging Navajo women in clean energy development through applied theatre. Res Drama Educ 20(2):242-257. https://doi. org/10.1080/13569783.2015.1019445
Ratner C (2009) Cooperativism: a social, economic, and political alternative to capitalism. Capital Nat Soc 20(2):44-73. https:// doi.org/10.1080/10455750902941086

Renou X (2015) Disobedience. In: D’Alisa G, Demaria F, Kallis G (eds) Degrowth: a vocabulary for a new era. Routledge, Abingdon, pp 162-164

Ritchie J, Spencer L, O'Connor W (2003) Carrying out qualitative analysis. In: Ritchie J, Lewis J (eds) Qualitative research practice: a guide for social science students and researchers. Sage, London, pp 219-262

Romano O (2015) Dépense. In: D’Alisa G, Demaria F, Kallis G (eds) Degrowth: a vocabulary for a new era. Routledge, Abingdon, pp 86-89

Schwartzman D (2012) A critique of degrowth and its politics. Capital Nat Soc 23(1):119-125

Sekulova F (2015) Happiness. In: D’Alisa G, Demaria F, Kallis G (eds) Degrowth: a vocabulary for a new era. Routledge, Abingdon, pp 63-66

Silverman D (2013) Doing qualitative research. Sage Publications, Thousand Oaks

Tàbara JD, Pahl-Wostl C (2007) Sustainability learning in natural resource use and management. Ecol Soc. https://doi.org/10.5751/ ES-02063-120203

Tarrow SG (2011) Power in movement: social movements and contentious politics. Cambridge University Press, Cambridge

Van den Bergh J (2011) Environment versus growth-A criticism of "degrowth" and a plea for "a-growth". Ecol Econ 70(5):881-890

Wamsler C, Brossmann J, Hendersson H, Kristjansdottir R, McDonald C, Scarampi P (2017) Mindfulness in sustainability science, practice, and teaching. Sustain Sci 13(1):143-162. https://doi. org/10.1007/s11625-017-0428-2

Wenger E (2009) A social theory of learning. In: Illeris K (eds) Contemporary theories of learning: learning theorists ... in their own words, Routledge, London, pp 209-218

Williams PJ (2012) Emergent themes. In: Given LM (eds) The Sage encyclopedia of qualitative research methods. Sage Online, Thousand Oaks. https://sk.sagepub.com.ludwig.lub.lu.se/reference/ research/n129.xml. Accessed 8 May 2017

Publisher's Note Springer Nature remains neutral with regard to jurisdictional claims in published maps and institutional affiliations. 